\title{
Membangun Motivasi (Self Transendence) Pendidik di MI Muhammadiyah Al-Muttaqien Sleman
}

\author{
Juwita Kusuma Wulandari', Robi'ah Nugrahani ${ }^{2}$ \\ ${ }^{1}$ FITK UIN Sunan Kalijaga Yogyakarta, Indonesia \\ ${ }^{2}$ FITK UIN Sunan Kalijaga Yohyakarta, Indonesia \\ 1juwita.kusuma23@gmail.com \\ 2robiahnugrahani047@gmail.com
}

\begin{abstract}
Abstrak:
Penelitian yang berjudul Membangun Motivasi (Self Transendense) Pendidik di MI Muhammadiyah Al-Muttaqien ini bertujuan untuk mengetahui peran lembaga atau pun kepala sekolah sebagai motivator untuk mengoptimalkan kinerja guru di MI Muhammadiyah AlMuttaqien. Penelitian ini merupakan penelitian dengan pendekatan kualitatif yang bersifat deskriptif. Subjek penelitian ini meliputi kepala sekolah dan guru yang mengajar di MI Muhammadiyah Al-Muttaqien. Teknik pengumpulan data yang digunakan adalah wawancara dan observasi. Teori yang digunakan ialah teori Hierarki kebutuhan Maslow (Hierarchy Of Need) yang didalamnya terdapat beberapa tingkatan kebutuhan yang diperlukan dalam meningkatkan motivasi kerja. Dalam penelitian teori ini dipakai untuk mengetahui ketercapaian kebutuhan spiritual para guru yang mengajar di MI Muhammadiyah AlMuttaqien. Juga apakah seluruh kebutuhan yang terdapat dalam teori Maslow ini sudah dapat terpenuhi oleh lembaga sehingga dapat meningkatkan motivasi kerja para guru. Hasil penelitian menunjukan bahwa peranan lembaga dan kepala sekolah dalam meningkatkan motivasi, sarana juga penghargaan terhadap kinerja para guru memang sangat dibutuhkan. Namun adanya kekurangan atau pun keterbatasan dalam hal alokasi dana dan lain hal membuat beberapa hal dalam tingkat kebutuhan tersebut menjadi tidak terpenuhi. Walau adanya kekurangan dalam hal tersebut, semangat dari para guru untuk terus mengajar dan ikhlas dalam menyampaikan ilmu pengetahuan merupakan hal penting yang mewujudkan self transcendence tersebut.
\end{abstract}


Juwita Kusuma Wulandari, Robi'ah Nugrahani

Kata Kunci: Motivasi, Self Transcendence, Kinerja Pendidik.

\begin{abstract}
:
The research, entitled Building Educator Motivation (Self Transcendence) at MI Muhammadiyah Al-Muttaqien aims to determine the role of the institution or the principal as a motivator to optimize teacher performance at MI Muhammadiyah Al-Muttaqien. This research is a research with a qualitative approach that is descriptive. The subjects of this study include principals and teachers who teach at MI Muhammadiyah Al-Muttaqien. The data collection techniques used were interviews and observation. The theory used is Maslow's Hierarchy of Need theory in which there are several levels of needs needed to increase work motivation. In research, this theory is used to determine the achievement of the spiritual needs of teachers who teach at MI Muhammadiyah Al-Muttaqien. Also, whether all the needs contained in Maslow's theory can be met by the institution so that it can increase the work motivation of teachers. The results showed that the role of institutions and school principals in increasing motivation, as well as means of rewarding the performance of teachers is really needed. However, there are shortcomings or limitations in terms of fund allocation and other things that make several things in the level of need not fulfilled. Even though there are deficiencies in this, the enthusiasm of the teachers to continue to teach and be sincere in conveying knowledge are important things that create self-transcendence.
\end{abstract}

Keywords: Motivation, Self Transcendence, Performance of Educators.

\title{
Pendahuluan
}

Pada pertengahan abad 20, psikologi humanistik juga dikenal sebagai the Third Force atau Aliran Ketiga lahir dan berkembang menjadi pendekatan yang populer dan adekuat dalam memahami dimensi psikis manusia (Grov). Pendiri maupun juru bicara yang paling representatif dari Aliran Ketiga ini adalah Abraham Harold Maslow. Humanistik berupaya untuk memberikan gambaran mengenai manusia secara holistik dan komprehensif dengan berpegang pada keyakinan fundamental bahwa manusia memiliki potensi untuk terus tumbuh mengarah pada kebaikan dan memiliki kapasitas untuk mengaktualisasikan diri seoptimal mungkin. Gambaran komprehensif untuk menjelaskan kepribadian maupun dinamika motivasi manusia ini Maslow tuangkan dalam teorinya mengenai Hierarki Kebutuhan atau Hierarchy of Need. Di dalam teori ini, Maslow juga menyebutkan bahwa manusia memiliki kebutuhankebutuhan yang tersusun secara hierarkis. Agar dapat terus berkembang, maka kebutuhan- 
kebutuhan tersebut harus dipenuhi secara bertahap dimulai dari kebutuhan biologis yakni sebagai kebutuhan yang paling mendasar, hingga kebutuhan aktualisasi-diri sebagai puncaknya. $^{1}$

Manajemen pendidikan merupakan segenap perbuatan yang menggerakan sekelompok orang dalam menggunakan fasilitas untuk suatu kerjasama dalam mencapai tujuan tertentu. Sedangkan usaha kerjasama yang dimaksudkan adalah bidang pendidikan. Sementara kelompok orang yang dimaksud adalah mereka yang berada dalam lingkup pendidikan (stake holder). Tujuan yang dimaksud adalah tujuan pendidikan Nasional seperti tercantum dalam Undang-Undang RI No.20 tahun 2003 tentang Sistem Pendidikan Nasional yaitu pendidikan adalah usaha sadar dan terencana untuk mewujudkan suasana belajar dan proses pembelajaran agar peserta didik secara aktif mengembangkan dirinya untuk memiliki kekuatan spiritual keagamaan, kepribadian, kecerdasan, akhlak mulia, serta keterampilan yang diperlukan dirinya, masyarakat, bangsa dan Negara. Untuk mencapai tujuan tersebut diperlukan motivasi yang tinggi. ${ }^{2}$

Pendidikan dan pengajaran adalah suatu proses yang sadar tujuan, yang berarti bahwa suatu usaha untuk memberikan gambaran hasil yang diharapkan siswa setelah melaksanakan pengalaman belajar. Tercapai tidaknya tujuan pengajaran salah satunya adalah terlihat dari prestasi belajar yang diraih siswa. Dengan prestasi yang tinggi, para siswa mempunyai indikasi berpengetahuan yang baik. $^{3}$

Orientasi dari semua organisasi atau lembaga adalah menuju pada pencapaian yang maksimal terhadap target-target yang telah di tentukan. Untuk mencapai hasil atau target yang maksimal ini tentunya di dasari oleh kinerja dan sinegitas yang baik dari SDM dari setiap posisi yang tentunya di pimpin secara garis organisasi oleh leader atau manajer. Guna mengupayakan kinerja maksimal dari karyawan atau pegawai dalam lembaga perlu adanya dorongan, dan salah satu yang harus dilakukan oleh pemimpin dalam suatu lembaga guna meningkatkan kinerja yaitu adanya dorongan motivasi.

Peran pemimpin dalam lembaga atau organisasi menjadi garda terdepan bergeraknya organisasi. Dengan posisi strategis secara garis organisasi seorang pemimpin atau leader maka

\footnotetext{
${ }^{1}$ Frank G. Goble, The Third Force, The Psychology Of Abraham Maslow. (Yogyakarta: Kanisius, 1989), hlm 23 .

${ }^{2}$ Sardiman A.M.,Interaksi Dan Motivasi Belajar-Mengajar . (Jakarta: PT Raja Grafindo Persada, 2011) hlm 73 .

${ }^{3}$ Ghullam Hamdu dan Nisa Agustina, "Pengaruh Motivasi Belajar Siswa Terhadap Prestasi Belajar IPA di Sekolah Dasar”, Jurnal Penelitian Pendidikan, Vol. 12, 1 April 2011, 90-91.
} 
perannya sangatlah vital. Salah satu yang perlu direspon dengan cepat oleh seorang pemimpin dalam lembaga adalah dinamika lembaga, yang tentunya dinamika ini didasari adanya pergerakan secara kelompok dari SDM lembaga yang tersusun dari indvidu-individu SDM. Dinamika inilah yang kadangkala berakibat bergesernya atau melemahnya tahapan untuk mencapai target organisasi.

\section{Pembahasan}

Kata "motif", diartikan sebagai daya upaya yang mendorong seseorang untuk melakukan sesuatu. Motif dapat dikatakan sebagai daya penggerak dari dalam dan didalam subjek untuk melakukan aktivitas-aktivitas tertentu demi mencapai suatu tujuan. Berawal dari kata "motif" itu, maka motivasi dapat diartikan sebagai daya penggerak yang telah menjadi aktif. ${ }^{4}$ Islam tidak saja membatasi pada anjuran supaya belajar, bahkan menghendaki supaya seseorang itu terus-menerus melakukan pembahasan dan studi. Rasulullah bersabda :

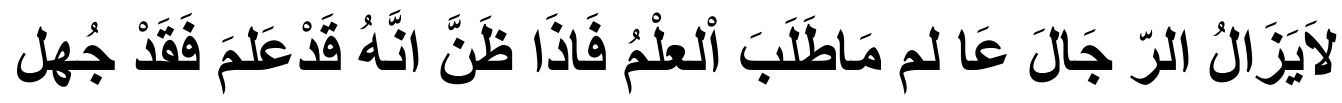

Artinya :

"seseorang itu dapat dianggap seorang yang alim dan berilmu, selama ia masih terus belajar. Apabila ia menyangka bahwa ia sudah serba tahu, maka ia sesungguhnya seorang jahil". 5

Islam menganggap bahwa agama tidak akan mendapat tempat yang baik apabila orangorang Islam tidak mempunyai pengetahuan yang matang dan fikiran yang sehat. Oleh karena itu pengetahuan bagi Islam bagaikan ruh (nyawa) bagi manusia. Dalam belajar (menuntut ilmu), Islam tidak membedakan antara laki-laki dan perempuan, sebagaimana sabdanya:

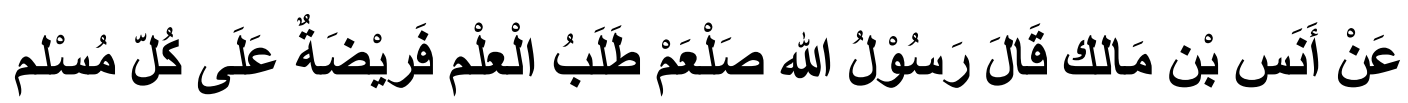

"Dari Anas ra, ia berkata: Rasulullah saw bersabda: Menuntut ilmu itu adalah kewajiban bagi setiap muslim" (HR. Baihaqi). ${ }^{6}$

Menuntut ilmu itu adalah suatu kewajiban bagi setiap insan yang beriman kepada Allah, dan orang Islam yang menuntut ilmu berarti ia telah mentaati perintah Allah dan Rasul-Nya,

\footnotetext{
${ }^{4}$ Sardiman A.M, Interaksi \& Motivasi..,hlm 74.

${ }^{5}$ Abubakar Muhammad, Hadits Tarbiyah I, (Surabaya: al-Ikhlas, 1995), hlm. 233.

${ }^{6}$ Muhammad al-Ghazali, Akhlaq seorang Muslim, Terj. Moh. Rifa'i (Semarang: Wicaksana, 1993), hlm.
} 445. 
karena Allah memerintahkan kepada setiap mukmin untuk menuntut ilmu. Tanpa ada pembedaan, agama Islam menganjurkan setiap lelaki dan perempuan belajar serta menggunakan ilmu yang dimilikinya, juga untuk mengembangkan dan menyebarkan ilmunya. Islam tidak saja membatasi pada anjuran supaya belajar, bahkan menghendaki supaya seseorang itu terus menerus melakukan pembahasan, mencari dan belajar. ${ }^{7}$

Istilah motivasi dalam kaidah bahasa Indonesia berasal dari kata motif yang berarti kekuatan yang ada dalm diri individu, yang menyebabkan individu tersebut bertindak atau berbuat. Motif tidak dapat diamati secara langsung, tetapi dapat diinterpretasikan dalam tingkah laku, berupa rangsangan, dorongan atau pembangkit tenaga untuk melakukan tingkah laku tertentu. Istilah motivasi berasal dari kata motif yang dapat diartikan sebagai kekuatan yang terdapat dalam diri individu, yang menyebabkan individu tersebut bertindak atau berbuat.

Dalam pengertian lain diterangkan bahwa pengertian motivasi adalah daya penggerak dalam diri seseorang untuk melakukan aktifitas tertentu demi mencapai tujuan tertentu. ${ }^{8}$ Dari beberapa penjelasan diatas dapat disimpulkan bahwa motivasi ialah adanya dorongan yang menggerakkan seseorang untuk bertingkah laku. Maka, perbuatan seseorang yang didasarkan atas motivasi tertentu mengandung tema atau maksud dengan motivasi yang mendasarinya.

\section{Self Transendence Pada Teori Motivasi Abraham Maslow}

Hierarki ini di dasarkan pada anggapan bahwa pada waktu orang telah memuaskan suatu tingkat kebutuhan tertentu, mereka ingin bergeser ke tempat yang lebih tinggi. ${ }^{9}$ Maslow mengungkapkan lima tingkat kebutuhan seperti ${ }^{10}$; Kebutuhan fisiologis, Rasa aman, Cinta kasih, Penghargaan, Aktualisasi diri. Namun pada tahun 1969 Malow ${ }^{11}$ merevisi karyanya dengan menambahkan transendensi diri yang merupakan tingkat motivasi yang paling tinggi dari teori Hirarki kebutuhannya.

Menurut Abraham Maslow, untuk mengembangkan potensi yang ada pada diri seseorang secara penuh harus di dongkrak oleh penekanan suatu motivasi, yang dikenal

\footnotetext{
${ }^{7}$ Muhammad 'Athiyah al-Abrasyi, Dasar-Dasar Pokok Pendidikan Islam, Terj. Bustami A. Gani dan Djohar Bahry (Jakarta: Bulan Bintang, 1974), hlm. 44.

${ }^{8}$ Ibid .,

${ }^{9}$ Hamzah B.Uno, Teori Motivasi dan Pengukurannya 'Analisis di Bidang pendidikan',(Jakarta: Bumi Aksara,2008) hlm 40.

${ }^{10}$ Ibid 41.

${ }^{11}$ Koltko Rivera, dalam jurnal Internasional Rediscovering the Later Version of Maslow's Hierarchy of Need (Self Trancendence and Opportunities for Theory, Research, and Unification,2006), hlm 303
} 
Juwita Kusuma Wulandari, Robi’ah Nugrahani

dengan istilah "Teori Motivasi Abraham Maslow". ${ }^{12}$ Penemuan Maslow akan konsep transendensi-diri ini tidak hanya memberi perubahan pada kerangka berpikir humanistik, tetapi juga merupakan awal bagi lahirnya disiplin ilmu baru, salah satunya psikologi transpersonal.

Posisi kebutuhan transendensi-diri yang berada di puncak hierarki kebutuhan melampaui aktualisasi-diri menyiratkan bahwa aktualisasi-diri bukan merupakan akhir dari perkembangan manusia, melainkan bagian dari proses pengembangan potensi manusia yang berlangsung secara terus-menerus, dengan transendensi-diri sebagai potensi tertinggi yang dapat dicapai oleh manusia.

Dalam teorinya sendiri tentang motivasi, Maslow mengemukakan ada lima tingkatan kebutuhan pokok manusia. Kelima tingkatan inilah yang kemudian dijadikannya pengertian kunci dalam memahami motivasi manusia. Maslow mengidentifikasi kebutuhan pokok atau kebutuhan dasar manusia dalam sebuah hierarki terendah yang bersifat biologis sampai tingkat tertinggi yang mengarah pada kemajuan dan kepuasan individu, istilah tingkatan ini biasa disebut dengan "Teori Hierarki Kebutuhan Maslow". ${ }^{13}$

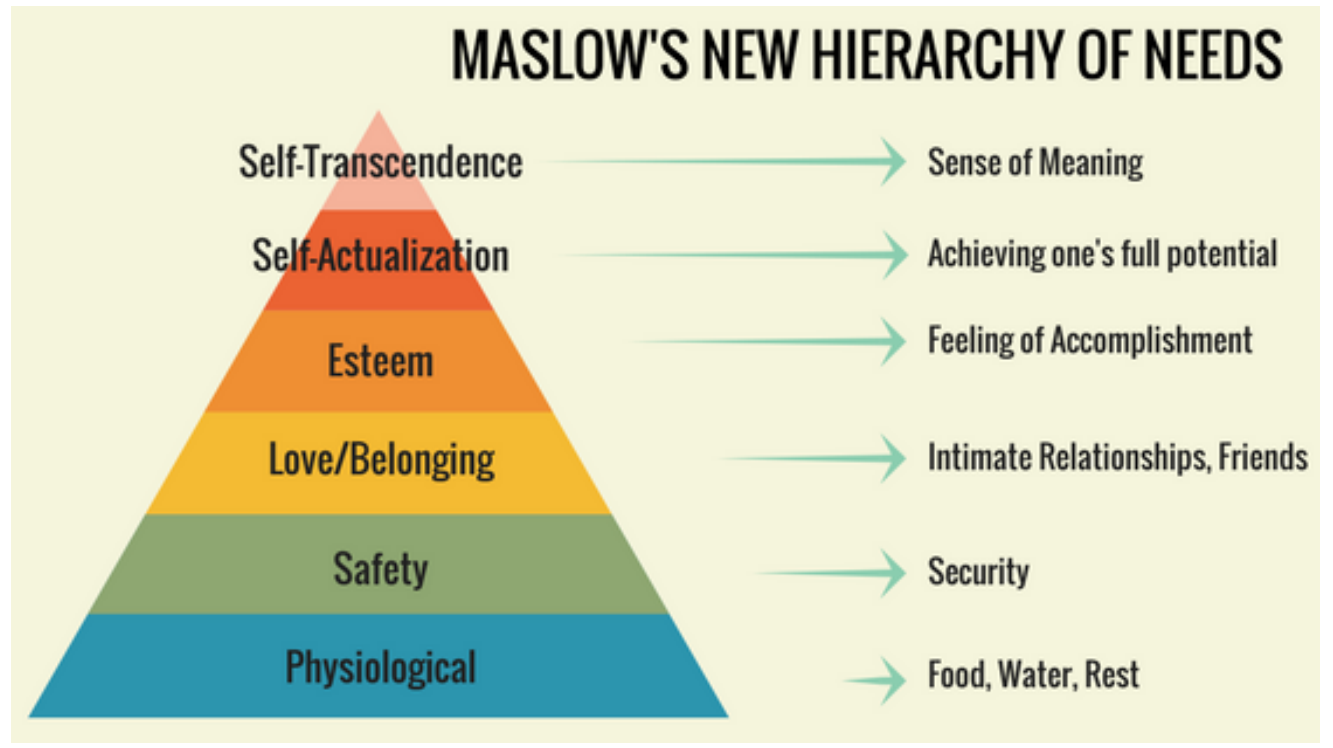

Aktualisasi diri merupakan puncak dari tingkatan hierarki kebutuhan maslow, yang dimulai dari tingkatan terendah yaitu kebutuhan fisiologi, rasa aman, cinta (social), harga diri, dan yang terakhir sampailah pada kebutuhan aktualisasi diri.

a. Kebutuhan Fisiologis

\footnotetext{
${ }^{12}$ Dale H. Schunk, Learning Theories An Aducation Perspective: Teori-Teori Pembelajaran Perspektif Pendidikan, (Yogyakarta: Pustaka Pelajar, 2012), hlm 482

${ }^{13}$ Frank G. Goble, The Third Force, ibid.,hlm 44. 
Kebutuhan Fisiologis merupakan sekumpulan kebutuhan dasar yang mendesak pemenuhannya karna berkaitan langsung dengan kelangsungan hidup manusia, seperti kebutuhan akan makanan, minuman, istirahat, seks dan lain sebagainya.Karna merupakan kebutuhan yang paling mendesak, maka kebutuhan fisiologis akan didahulukan pemenuhannya oleh individu.

b. Kebutuhan Keamanan

Apabila kebutuhan dasar fisiologis telah terpenuh, maka akan muncul seperangkat kebutuhan baru. Yaitu, kebutuhan akan keselamatan (keamanan, kemantapan, ketergantungan, perlindungan, bebas dari rasa takut, hukum, dll).

Dalam konteks pendidikan, menurut maslow, anak atau peserta didik akan memperoleh rasa aman yang cukup apabila ia berada dalam ikatan keluarga. Oleh sebab itu, kehidupan keluarga yang harmonis dan normal merupakan sebuah kebutuhan yang tidak dapat ditawar lagi bagi peserta didik.

c. Kebutuhan Cinta dan Kasih Sayang (Social)

Apabila kebutuhan fisiologi dan keselamatan cukup terpenuhi, maka akan muncul kebutuhan lebih tinggi lagi, yaitu kebutuhan akan cinta dan kasih sayang. Hal ini sudah menjadi kodrat manusia bahwa ia akan selalu bergantung pada manusia lain, terutama dalam dalam hal cinta dan kasih sayang. Kebutuhan cinta dan kasih sayang mampu mendorong individu untuk mengadakan hubungan efektif atau ikatan emosional dengan individu yang lain, baik dilingkungan keluarga, masyarakat, maupun sekolah. Namun ketika cinta dan kasih sayang tidak didapatkan maka anak akan merasakan perihnya rasa kesepian, pengucilan social, penolakan, tiadanya keramahan, sehingga menimbulkan keadaan psikologi yang tidak menentu yang akan membuat proses belajar anak menjadi tidak efektif.

d. Kebutuhan Harga Diri (Ego)

Setelah kebutuhan akan cinta dan kasih sayang sudah terpenuhi, kebutuhan mendasar berikutnya yang muncul adalah kebutuhan harga diri. Apabila kebutuhan akan harga diri sudah dapat terpenuhi, maka seseorang akan lebih percaya diri, optimis, dan merasa berguna. Sebaliknya, apabila pemuasan kebutuhan akan harga diri terhambat, maka dia akan merasa rendah diri, pesimis, lemah, dan tak berguna. Bahkan ia akan memiliki penilaian yang rendah atas dirinya dalam kaitannya dengan orang lain. Oleh sebab itu, harga diri yang stabil dan sehat diperoleh dari penghargaan yang wajar dari orang lain.

e. Kebutuhan Aktualisasi Diri 
Aktualisasi diri dapat didefinisikan sebagai perkembangan dari individu yang paling tinggi, mengembangkan segala potensi yang dimiliki dan menjadikan segala sesuatu menurut kemampuannya. ${ }^{14}$ Menurut Robert, aktualisasi diri adalah kemampuan seseorang mengembangkan potensi penuhnya, yang dicirikan oleh penerimaan terhadap dirinya sendiri dan orang lain, spontanitas, keterbukaan, kreativitas, ekspresi diri, hubungan yang relative mendalam, tatapi demokratis terhadap orang lain, humor, dan kebebasan. ${ }^{15}$ Humanisme dalam pendidikan adalah proses proses pendidikan yang lebih memperhatikan aspek potensi manusia sebagai makhluk social dan religious, serta sebagai individu yang diberikan kesempatan oleh Tuhan untuk mengembangkan potensinya secara maksimal.

Menurut maslow, untuk mencapai tingkat aktualisasi diri, setiap individu harus memenuhi empat tingkat yankebutuhan sebelumnya. Karna setiap individu tidak akan lagi direpotkan oleh masalah mencari makan, tidak akan lagi dihiraukan oleh ancaman keamanan, memiliki banyak teman yang akrab serta penuh rasa kasih sayang yang selau memiliki rasa perasaan dihargai.

f. Self transcendence

Kebutuhan ini merupakan kebutuhan yang berada dalam urutan puncak Hierarchy of need Abraham Maslow. Self transcendence merupakan kebutuhan manusia untuk "bergerak" keluar diri dan terhubung dengan sesuatu yang lebih besar dari diri kita sendiri. Seperti ingin lebih dekat dengan Tuhan atau manusia bergerak dan melakukan sesuatu diluar egonya. Pada tingkat ini kebutuhan individu dikesampingkan dan lebih mengutamakan kebutuhan orang lain seperti membantu orang lain tanpa mengharapkan imbalan dan juga ikhlas melakukannya.

Dimasukkannya transendensi diri dalam hierarki Maslow memungkinkan adanya konsep yang lebih kaya dari pada dimensi pandangan dunia akan makna hidup itu sendiri. Dengan membuat cara pandang kita terhadap dunia lebih komprehensif atau lebih luas, kita pada akhirnya akan mendapatkan pemahaman dan pengetahuan yang lebih baik dalam memahami kepribadian dan juga psikologi sosial. ${ }^{16}$ Self transendance sendiri merupakan bagian dari teori Maslow yang saling berintegrasi dengan teori lain seperti psikologi.

\footnotetext{
${ }^{14}$ Chairul Anwar, Teori Teori....., hlm.261

${ }^{15}$ Robert E. Salvin, Psikologi Pendidikan: Teori dan Praktik, (Jakarta: Indeks Permata Putri Media, 2009), hlm. 135.

${ }^{16}$ Koltko Rivera, Rediscovering the Later Version of Maslow's Hierarchy of Needs:Self-Transcendence and Opportunities for Theory, Research,and Unification, ( Journal General Psychology 2006, Vol 10 no 4) ,hlm 310 .

222 |Ilmu Al-Qur'an (IQ) Jurnal Pendidikan Islam | Volume 02 No.2 2019
} 
Memahami Self transcendence sebagai bagian dari hirarki maslow merupakan dasar yang amat penting apabila seorang peneliti hendak mengembagkan pemahaman tentang : ${ }^{17}$

i. Pemahaman yang lebih luas tentang pandangan dunia mengenai makna kehidupan.

ii. Pemahaman yang lebih luas tentang akar motivasi altruism, kemajuan sosial, kebijaksanaan manusia.

iii. Pengetahuan tentang kekerasan beragama.

iv. Integrasi psikologi agama dan spiritualitas menjadi jalan utama psikologi.

v. Berbagai multikultural terintegrasi pada pendekatan teori psikologi.

Dari penjelasan diatas, dapat peneliti simpulkan bahwa adanya amandemen ulang terhadap teori self transcendence oleh maslow sangatlah diperlukan. Seperti multidisipliner ilmu yang saling membangun satu sama lain. Begitu pula dengan teori self transcendence milik Maslow, dapat menjadi dasar untuk berbagai pengetahuan atau pemahman seseorang terhadap diri sendiri, masyarakat sosial bahkan pandangan diri terhadap dunia.

\section{Praxis Teori Kebutuhan (Hierarchy of Neeed) Maslow di MI Muhammadiyah Al- Muttaqien}

MI Muhammadiyah AL-Muttaqien merupakan Madrasah Ibtidaiyah di daerah Medari Cilik, Caturharjo, Sleman, Yogyakarta. Sekolah ini dibawah pimpinan Ibu Isna Fathurrahmah, S.Pd. I selaku kepala sekolah. Di bawah ini akan peneliti jabarkan pembahasan tentang praxis teori kebutuhan yang di dalamnya terdapat motivasi self transendence pada pengajar di MI Muhammadiyah Al-Muttaqien. Penjabaran ini berdsarkan hasil anailis yang dilakukan peneliti yang dikumpulkan dari hasil observasi dan wawancara. Dari hasil wawancara tersebut didapatkan hasil wawancara sebagai berikut :

a. Kebutuhan fisiologis merupakan kebutuhan yang paling mendasar, yaitu kebutuhan primer seperti makanan, pakaian, rumah dan sebagainya. Berdasarkan hasil wawancara, ada perbedaan penghasilan yang didapatkan diantara guru honorer dan guru tetap atau guru yang telah mendapat sertifikasi maupun yang pns. Penghasilan yang di dapatkan para guru honorer di sekolah ini perbulannya Rp 200.000 . Sementara untuk guru yang telah mendapatkan sertifikasi akan mendapatkan tunjangan sesuai golongan guru tersebut. Contohnya jika ada seorang guru yang telah mendapatkan sertifikasi dengan golongan 3B akan mendapatkan

\footnotetext{
${ }^{17}$ Koltko Rivera, Rediscovering the Later Version of Maslow's Hierarchy of Needs:Self-Transcendence and Opportunities for Theory, Research,and Unification, ( Journal General Psychology 2006, Vol 10 no 4), hlm 01
} 
tunjangan Rp 2.400.000. Sekitar 2-5 bulan sekali". ${ }^{18}$ Sedangkan untuk gaji guru PNS tentunya sudah memenuhi kebutuhan mereka sehari-hari, juga dengan adanya tambahan tunjangan dari pemerintah membuat kebutuhan fisiologis mereka secara bertahap terpenuhi. ${ }^{19}$ Kebutuhan papan seperti rumah, sekolah tidak menyediakan secara khusus akan hal itu tetapi untuk beberapa guru sudah terpenuhi secara individu sebelumnya. Sedangkan untuk kebutuhan pakaian sudah terpenuhi dengan biaya masing-masing guru. Untuk beberapa keperluan seragam bersama terkadang akan membutuhkan dana dari uang kas guru. ${ }^{20}$

Dari penjelasan di atas dapat kita ketahui bahwa guru di MI Muhammadiyah laMuttaqien hampir terpenuhi kebutuhannya secara fisiologis. Walaupun ada perbedaan dalam perolehan gaji untuk beberapa guru hal tersebut dikarnakan perbedaan antara guru yang belum memperoleh sertifikasi dan yang belum.

b. Kebutuhan rasa aman dan perlindungan yang berdasarkan observasi dan juga wawancara yang peneliti lakukan di lapangan bahwa sekolah tidak memiliki tenaga keamanan di wilayah sekolah. Keamanan untuk para murid sendiri dilakukan oleh para guru pada saat siswa keluar kelas atau pun pulang sekolah. ${ }^{21}$ Terkadang guru kelas juga memastikan dan mengawasi murid yang belum di jemput oleh orang tua hingga orang tua mereka datang menjemput. Hal tersebut dilakukan oleh para guru untuk memastikan keamanan para siswa dan juga secara tidak lagsung membangun kepercayaan antara murid dan guru. Sehingga ketika terjadi suatu yang tidak diinginkan di sekolah para siswa tidak akan segan atau malu untuk bercerita kepada guru mereka. Sedangkan untuk para guru sendiri karena adanya keterbatasan dana yang dimiliki oleh sekolah menjadikan belum terpenuhinya kebutuhan rasa aman tersebut dengan maksimal.

c. Kebutuhan sosial merupakan kebutuhan untuk saling berinteraksi antara seorang individu dengan individu lainnya dalam kehidupan bermasyarakat. Berdasarkan hasil wawancara, menurut peneliti lingkungan sekolah sangatlah kondusif bagi murid dan guru untuk melangsungkan proses belajar mengajar. Hal ini dapat membagun rasa sosialisasi para siswa

\footnotetext{
${ }^{18}$ Hasil wawancara dengan Ibu Anna Miftahurohmah, Guru Honorer MI Muhammadiyah Al-Muttaqien, Medari Cilik, Caturharjo, Sleman, Yogyakarta, pada Tanggal 11 April 2019 pukul 09.30 WIB.

${ }^{19}$ Hasil wawancara dengan Ibu Murtilah, Guru MI Muhammadiyah Al-Muttaqien, Medari Cilik, Caturharjo, Sleman, Yogyakarta, pada Tanggal 11 April 2019 pukul 10.00 WIB.

${ }^{20}$ Hasil wawancara dengan Ibu Murtilah, Guru MI Muhammadiyah Al-Muttaqien, Medari Cilik, Caturharjo, Sleman, Yogyakarta, pada Tanggal 11 April 2019 pukul 10.00 WIB.

${ }^{21}$ Hasil wawancara dengan Ibu Isna Fathurrohmah, Kepala Sekolah MI Muhammadiyah Al-Muttaqien, Medari Cilik, Caturharjo, Sleman, Yogyakarta, pada Tanggal 11 April 2019 pukul 08.30 WIB.
} 
nantinya di masa depan dalam menghadapi masyarakat sosial yang leih luas. Begitu juga dengan hubungan antar guru yang harmonis. ${ }^{22}$

d. Kebutuhan penghargaan yang peneliti peroleh menurut hasil wawancara dari beberapa guru disekolah bahwa tidak ada penghargaan dalam bentuk apapun yang diberikan. Salah satu guru juga mengungkapkan bahwa terkadang para guru bekerja lembur tetapi tidak ada penghargaan yang diberikan oleh pihak sekolah maupun lembaga. ${ }^{23}$ Menurut analisis peneliti sendiri bahwa adanya kekurangan pada alokasi dana ataupun kurangnya musyawarah antar tenaga pengajar dan pengurus sekolah membuat kebutuhan ini belum terpenuhi. Namun, untuk menambah kualitas para pegawai dan tenaga pengajar, sekolah selalu memberikan kegiatas workshop dan pelatihan. ${ }^{24}$ Dengan adanya kegiatan workshop atau pelatihan setiap bulannya yang di sediakan oleh pihak lembaga juga merupakan suatu penghargaan dari sekolah menurut pandangan peneliti. Mereka bisa berbagi ilmu yang mungkin tidak bisa di dapatkan karna sibuk untuk mengajar dan mengerjakan pekerjaan lain.

Dari sudut pandang peneliti sendiri sangatlah penting untuk memberikan sebuah penghargaan bagi para pengajar. Hal itu dapat memunculkan rasa percaya diri dari para pengajar. Mereka juga akan lebih aktif dalam bekerja karena penghargaan tersebut. Sebuah apresiasi sanjungan atau penghargaan dalam bentuk apapun dapat mendongkrak semangat dan membuat yang menerimanya merasakan bahagia. Oleh sebab itu, terkadang dalam sebuah pekerjaan, seorang bos atau sebuah lembaga pasti akan memberika reward bagi para pekerjanya yang berhasil memenuhi standart kerja.

e. Kebutuhan aktualisasi diri merupakan kemampuan seseorang dalam mengembangkan potensi pribadi seutuhnya. Kebutuhan ini akan terwujud ketika kebutuhan-kebutuhan sebelumnya telah terpenuhi. Berdasarkan hasil wawancara untuk masalah pengembangan para guru sendiri sekolah mengadakan pengajian setiap minggu atau pengajian rutin. Selain itu juga diadkaan seminar untuk meningkatkan kinerja para guru di sekolah, kegiatan tersebut diadakan setiap bulan. ${ }^{25}$

${ }^{22}$ Hasil wawancara dengan Hasil wawancara dengan Ibu Murtilah, Guru MI Muhammadiyah AlMuttaqien, Medari Cilik, Caturharjo, Sleman, Yogyakarta, pada Tanggal 11 April 2019 pukul 10.00 WIB.

${ }^{23}$ Hasil wawancara dengan Hasil wawancara dengan Ibu Anna Miftahurohmah, Guru Honorer MI Muhammadiyah Al-Muttaqien, Medari Cilik, Caturharjo, Sleman, Yogyakarta, pada Tanggal 11 April 2019 pukul 09.30 WIB.

${ }^{24}$ Hasil wawancara dengan Ibu Isna Fathurrohmah, Kepala Sekolah MI Muhammadiyah Al-Muttaqien, Medari Cilik, Caturharjo, Sleman, Yogyakarta, pada Tanggal 11 April 2019 pukul 08.30 WIB.

${ }^{25}$ Hasil wawancara dengan Ibu Isna Fathurrohmah, Kepala Sekolah MI Muhammadiyah Al-Muttaqien, Medari Cilik, Caturharjo, Sleman, Yogyakarta, pada Tanggal 11 April 2019 pukul 08.30 WIB. 
Menurut peneliti hal tersebut belum bisa dikatakan sebagai aktualisasi diri. Sekolah mungkin telah menyediakan berbagai sarana berupa ilmu yang dapat para pengajar dapatkan untuk merealisasikan kebutuhan aktualisasi diri tersebut. Namun, ketika kita membicarakan aktualisasi diri para pengajar, hal ini tidak akan lepas dari keterpenuhnya kebutuhankebutuhan sebelumnya untuk para pengajar. Dilihat dari kebutuhan sebelumnya ada beberapa kebutuhan yang masih kurang dan belum terpenuhi seutuhnya untuk dapat mengembangkan bakat dan kemampuan. Seperti kebutuhan akan rasa aman, dan kebutuhan akan penghargaan sehingga para pengajar di MI Muhammadiyah Al-Mutaqien merasa bahwa mereka akan lebih dihargai dan juga menjadi lebih percaya diri kedepannya.

Self transendence merupakan kebutuhan manusia untuk bergerak diluar dari kebutuhannya sendiri dimana self transendence juga dikatakan sebagai kebutuhan spiritual. Berdasarkan hasil dari wawancara peneliti oleh salah satu guru di sekolah bahwa keihlasan dalam menjalani keseharian sebagai guru merupakan kunci kelancaran para guru dalam proses mengajar. ${ }^{26}$ Juga adanya rasa cinta pada dunia mengajar terutama mengajar anak-anak sangat membantu para guru dalam menyelesaikan tugas-tugas mengajar di sekolah. ${ }^{27}$ Dalam kebutuhan aktualisasi diri seseorang akan berusaha untuk memunculkan potensi diri. Namun dalam self transcendence seseorang akan mengenyampingkan kebutuhan pribadi untuk melayani suatu hal yang lebih besar dari dirinya sendiri. Dalam kasus ini, apabila kita berbicara mengenai seorang pengajar yang mengetahui dan memahami self transcendence, dirinya akan diperlihatkan akan kenikmatan dalam mengajar. Dimana saat mengajar ia dapat memberikan berbagai macam ilmu kepada para peserta didik tanpa harus memikirkan berbagai kebutuhan dan motivasi pada poin sebelumnya. Mengapa demikian? Telah dikatakan sebelumnya, ketika seseorang sudah mencapai self transcendence maka ia akan mengenyampingkan kebutuhan pribadi untuk melayani kebutuhan yang lebih besar dari dirinya. Tentu akan banyak fakor juga yang mempengaruhi seberapa besar kecintaan seorang pengajar terhadap dunia mengajar. Dari hasil wawancara dan observasi diatas dapat peneliti katakan bahwa selain lembaga yang berperan penting dalam meningkatkan motivasi kerja para guru juga pasti ada usaha dari para guru untuk memperbaharui kualitas mereka agar menjadi lebih baik.

\footnotetext{
${ }^{26}$ Hasil wawancara dengan Ibu Umi Khoiriyah, Guru MI Muhammadiyah Al-Muttaqien, Medari Cilik, Caturharjo, Sleman, Yogyakarta, pada Tanggal 11 April 2019 pukul 09.00 WIB.

${ }^{27}$ Hasil wawancara dengan Ibu Umi Khoiriyah, Guru MI Muhammadiyah Al-Muttaqien, Medari Cilik, Caturharjo, Sleman, Yogyakarta, pada Tanggal 11 April 2019 pukul 09.00 WIB
} 


\section{Kesimpulan}

Untuk mengembangkan potensi yang ada pada diri seseorang secara penuh harus di dongkrak oleh penekanan suatu motivasi, yang dikenal dengan istilah "Teori Motivasi Abraham Maslow/ teori hierarki kebutuhan”, yaitu: kebutuhan fisiologis, kebutuhan rasa aman, kebutuhan sosial, kebutuhan penghargaan, aktualisasi diri, dan yang terakhir self transendense. Dapat dikatakan bahwa apabila kebutuhan-kebutuhan tersebut terpenuhi maka dapat meningkatkan motivasi seorang atau pun kelompok. Oleh karena itu, menurut teori motivasi ini apabila seorang pemimpin atau pendidik bermaksud memberikan motivasi kepada seseorang (peserta didik), ia harus berusaha mengetahui terlebih dahulu kebutuhan-kebutuhan orang yang akan di motivasinya. Dengan begitu, dia akan sukses dalam memotivasi orang tersebut. Begitu pula dalam lembaga pendidikan dalam memenuhi setiap tingkat kebutuhan para pengajar. Mulai dari kebutuhan fisiologis, kebutuhan akan rasa aman, kebutuhan akan interaksi sosial, penghargaan, hingga aktualisasi diri sehingga dapat meningkatkan kreatifitas dan pencapaian para pengajar.

Dalam penelitian ini mengenai motivasi kerja para guru di MI Muhammadiyah Al-Muttaqien sangat dipengaruhi oleh bagus atau tidaknya fasilitas yang disediakan lembaga guna memenuhi berbagai kebutuhan tersebut. Namun pada praxisnya sendiri untuk dapat mencapai kebutuhan paling tinggi yakni self transendense, masih banyak poin-poin dari kebutuhan tersebut yang tidak terpenuhi. Meski begitu semangat para guru tidaklah luntur untuk mengajar karena didasari rasa ikhlas dan mencintai dunia mengajar. Menurut peneliti sendiri hakikat dari self transcendence masih sangat jauh dari kata terealisasi. Karena jika pada akhirnya untuk menumbuhkan rasa semangat pada setiap guru untuk mengajar tidak benar-benar dibangun dari motivasi yang seharusnya juga dari kelengkapan sarana dan prasarana yang belum bisa dipenuhi oleh pihak lembaga itu sendiri.

\section{Saran}

Adapun saran yang dapat penulis sampaikan dalam penyusunan makalah ini antara lain yaitu perlunya banyak literasi dan pemahaman dalam mengkaji pembahsan ini. Juga adanya keluesan dalam menerima pendapat dari beberapa tokoh dan literasi amat sangat membantu dalam pemahaman. Kepada seluruh pembaca, diharapkan kritik dan sarannya yang bersifat membangun demi memperbaiki makalah dan peneliti menjadi lebih baik lagi dimasa mendatang. 
Juwita Kusuma Wulandari, Robi'ah Nugrahani

\section{Daftar Pustaka}

Al-Abrasyi, Muhammad 'Athiyah. Dasar-Dasar Pokok Pendidikan Islam, Terj. Bustami A. Gani dan Djohar Bahry. Jakarta: Bulan Bintang. 1974.

Al-Ghazali Muhammad. Akhlaq seorang Muslim, Terj. Moh. Rifa'i. Semarang: Wicaksana. 1993.

Chairul Anwar. Teori Teori Pendidikan Klasik Hingga Kontemporer. Yogyakarta: Diva Press. 2017.

Fathurrohmah, Isna. Kepala Sekolah MI Muhammadiyah Al-Muttaqien, Medari Cilik, 2019. Caturharjo, Sleman. Wawancara Pribadi : 11 April 2019 pukul 08.30 WIB. Yogyakarta.

Goble, Frank G. The Third Force, The Psychology Of Abraham Maslow. Yogyakarta: Kanisius. 1989.

Khoiriyah, Umi. Guru MI Muhammadiyah Al-Muttaqien, Medari Cilik, Caturharjo, Sleman. Wawancara pribadi : 11 April 2019 pukul 09.00 WIB. Yogyakarta. 2019.

M, Sardiman A. Interaksi Dan Motivasi Belajar-Mengajar . Jakarta: PT Raja Grafindo Persada. 2011.

Miftahurohmah, Anna. Guru Honorer MI Muhammadiyah Al-Muttaqien, Medari Cilik, Caturharjo, Sleman. Wawancara pribadi : 11 April 2019 pukul 09.30 WIB. Yogyakarta. Muhammad, Abubakar. Hadits Tarbiyah I, Surabaya: al-Ikhlas. 1995.

Murtilah. Guru MI Muhammadiyah Al-Muttaqien, Medari Cilik, Caturharjo, Sleman. Wawancara pribadi : 11 April 2019 pukul 10.00 WIB. Yogyakarta.

Schunk, Dale H. Learning Theories An Aducation Perspective: Teori-Teori Pembelajaran Perspektif Pendidikan. Yogyakarta: Pustaka Pelajar. 2012.

Salvin, Robert E. Psikologi Pendidikan: Teori dan Praktik. Jakarta: Indeks Permata Putri Media. 2011.

Rivera, Koltko. Journal : Rediscovering the Later Version of Maslow's Hierarchy of Need: Self Trancendence and Opportunities for Theory, Research, and Unification. By American Psychological Asociation. 2006.

Uno, Hamzah B. Teori Motivasi dan Pengukurannya 'Analisis di Bidang pendidikan. Jakarta: Bumi Aksara. 2008. 